SINET: Ethiop. J. SCI., 25(2):227-252, 2002

(C) Faculty of Science, Addis Ababa University, 2002

\title{
THE GEOTECTONIC EVOLUTION OF THE WESTERN ETHIOPIAN SHIELD
}

Teklewold Ayalew ${ }^{1}$ and Timothy E. Johnson ${ }^{2}$

${ }^{1}$ Department of Geology and Geophysics, Faculty of Science, Addis Ababa University, PO Box 40105, Addis Ababa, Ethiopia, E-mail: ateklewold@hotmail.com

${ }^{2}$ Institute for Mineralogy and Petrology, Karl-Franzens University, A-8010 Graz, Austria, E-mail: timothy.johnson@kfunigraz.ac.at

\begin{abstract}
The western Ethiopian Shield comprises three lithotectonic units. The Birbir domain, an assemblage of mafic to felsic intrusive and extrusive rocks and mainly volcanogenic sedimentary rocks, is enclosed between the dominantly orthogneissic Baro and Geba domains. The earliest recorded deformation event (D1) resulted in the formation of a subhorizontal gneissosity within the gneissic terranes which was synchronous with an early upper amphibolite-facies metamorphic peak (M1) at 800-770 Ma which locally caused partial melting. All terrains were subsequently deformed in the D2 event which was the result of severe E-W crustal shortening. An anticlockwise P-T-t path is implied. Subsequent D3 deformation was concentrated within mylonitised domain boundaries which record major transcurrent movement. These structures were reactivated and suffered fluid incursion resulting in isotopic reequilibration at 635-580 Ma. A second metamorphic event, $\mathrm{M} 2$, related to crustal thickening and consequent granite genesis, occurred after the cessation of D3 shearing. Bulk chemical analyses show that the metamorphosed plutonic and volcanic rocks of the Birbir domain are predominantly calc-alkaline and similar to those generated by subduction in modern magmatic arcs. They belong in part to the low-K series, suggesting an oceanic environment. The evolution of the region can be explained in terms of the melting of a subducting slab, intrusion, metamorphism and the formation of an oceanic island arc complex. Continued plate convergence caused severe east-west shortening and basin closure. Further attenuation gave rise to transcurrent shearing, fluid influx, a second thermal event and accretion of microcontinents.
\end{abstract}

Key words/phrases: Accretion, cratonisation, isotope systems, subduction, transcurrent movement

\section{INTRODUCTION}

Although geological investigations of the relationship between the Neoproterozoic rocks of the Arabian-Nubian shield (ANS) and rocks of the Mozambique belt (MB), are still at an early stage, it has been possible to recognize three types of lithotectonic assemblages: volcano-sedimentary 
terranes, gneissic terranes and ophiolitic rocks (Vail 1985; Kröner, 1985; Shackleton, 1986; Seife Michael Berhe, 1990; Kröner et al., 1991; Stern, 1994; Abdelselam and Stern, 1996). Similar terranes are recognized in rocks of western Ethiopia (Kazmin et al., 1978; 1979; de Wit and Senbeto Chewaka, 1981; Teklewold Ayalew et al., 1990). The current contribution examines the geology of the Western Ethiopian Shield (WES) along the Gore-Gambella and Aba Sena-Gimbi-Inango-Ayra transects (Fig. 1) with a view to providing a geologically reasonable model to account for the tectonic evolution of the region.

\section{GEOLOGICAL SETTING}

The WES comprises low-grade, juvenile, metavolcanosedimentary rocks bounded to the east, west and south by gneissic rocks. Lithological, structural and metamorphic similarities between the gneissic rocks and the basement exposed further south (in Kenya, Uganda and SE Sudan) suggest that the former may be a northwards continuation of the Mozambique Belt (Kazmin et al.,1978; Seife Michael Berhe, 1990; Bonavia and Chrowicz, 1993; Samuel Gichile and Fyson, 1993). Similar considerations suggest that the juvenile rocks represent a southwards extension of the ANS from Sudan, Egypt and Saudi Arabia (Kazmin et al., 1978; Warden et al., 1982; Seife Michael Berhe, 1990; Teklewold Ayalew et al., 1990). Recent studies of the WES (e.g., Teklewold Ayalew et al., 1990; Seife Michael Berhe, 1990; Bonavia and Chrowicz, 1993; Samuel Gichile and Fyson, 1993) have alerted the scientific community to the potential of the region for the investigation of East African orogenic processes and, consequently, the evolution of Gondwana. Mengesha Tefera and Seife Michael Berhe (1987) and Moore et al. (1987) subdivided the WES into three discrete lithotectonic domains. The Birbir domain, having a low-grade (ANS) metavolcanosedimentary affinity, is tectonically bounded (Teklewold Ayalew, 1997) to the east and west, respectively, by the dominantly gneissic Geba and Baro domains (Fig. 2). Geochronological constraints (e.g., Teklewold Ayalew et al., 1990) suggest that the terrains have evolved in tectonothermal continuity during the Pan African orogeny (c. 650-550 Ma), although their precise relationship prior to this is less clear. N-S striking structures dominate Pan-African tectonics, although some gneisses preserve relics of granulite-facies metamorphism and contain E-W trending structures (e.g., Kazmin et al., 1978; Teklewold Ayalew and Moore, 1989; Mengesha Tefera and Seife Michael Berhe, 1987; Samuel Gichile, 1992) suggesting that they were affected by a pre-PanAfrican tectonothermal event. 


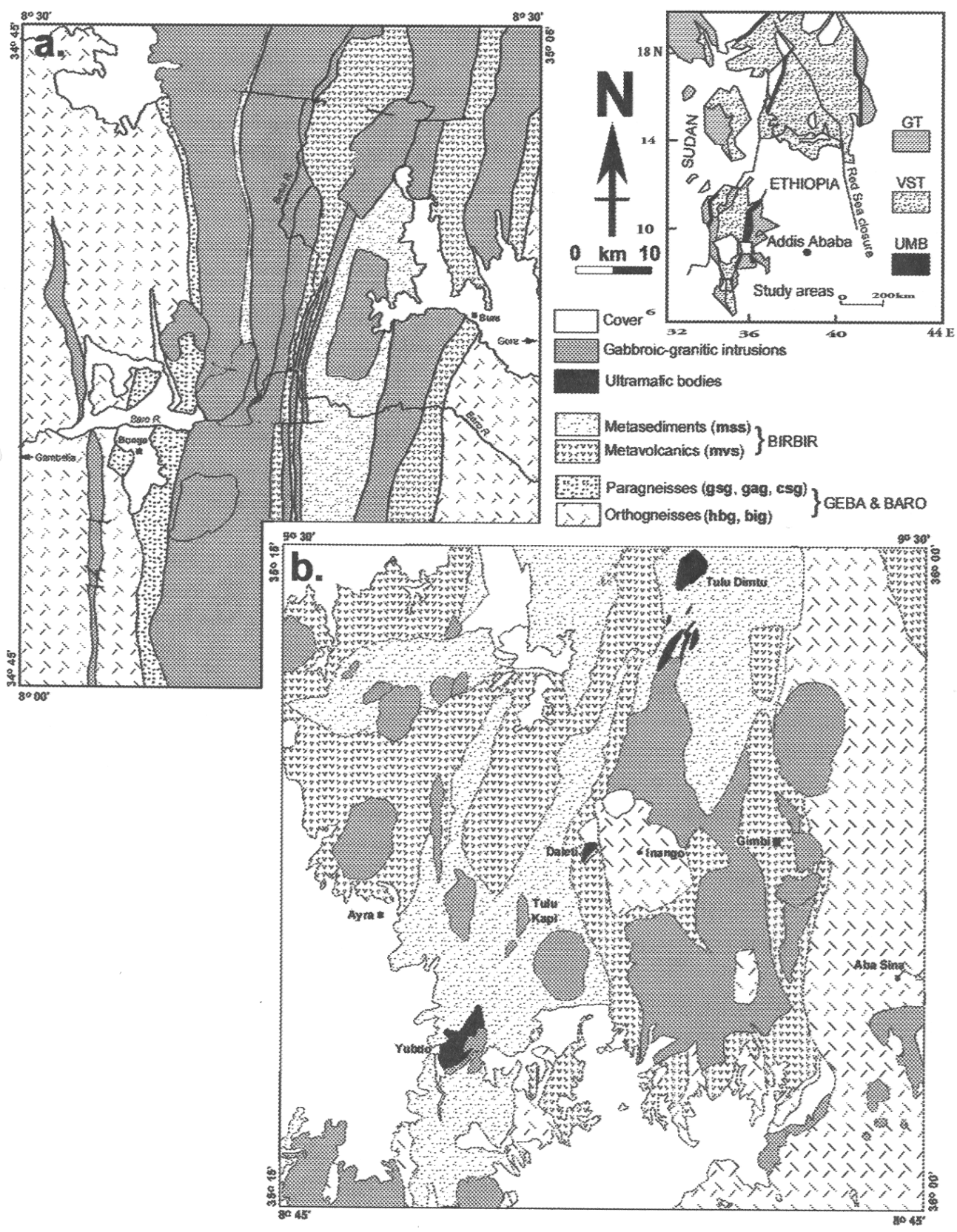

Fig. 1. Generalized geology of the Gore-Gambella area (a) after Teklewold and Moore (1989), and the Gimbi area (b) (modified after Braathen et al., 2001). The inset shows the distribution of gneissic terrains (GT), volcano-sedimentary terrains (VST) and ultramafic bodies (UMB) in the region. Intrusive and metaintrusive units: (1), Bonga; (2), Mao; (3), Bure; (4), Haya; (5), Goma; (6), Birbir; and (7) Baro. 

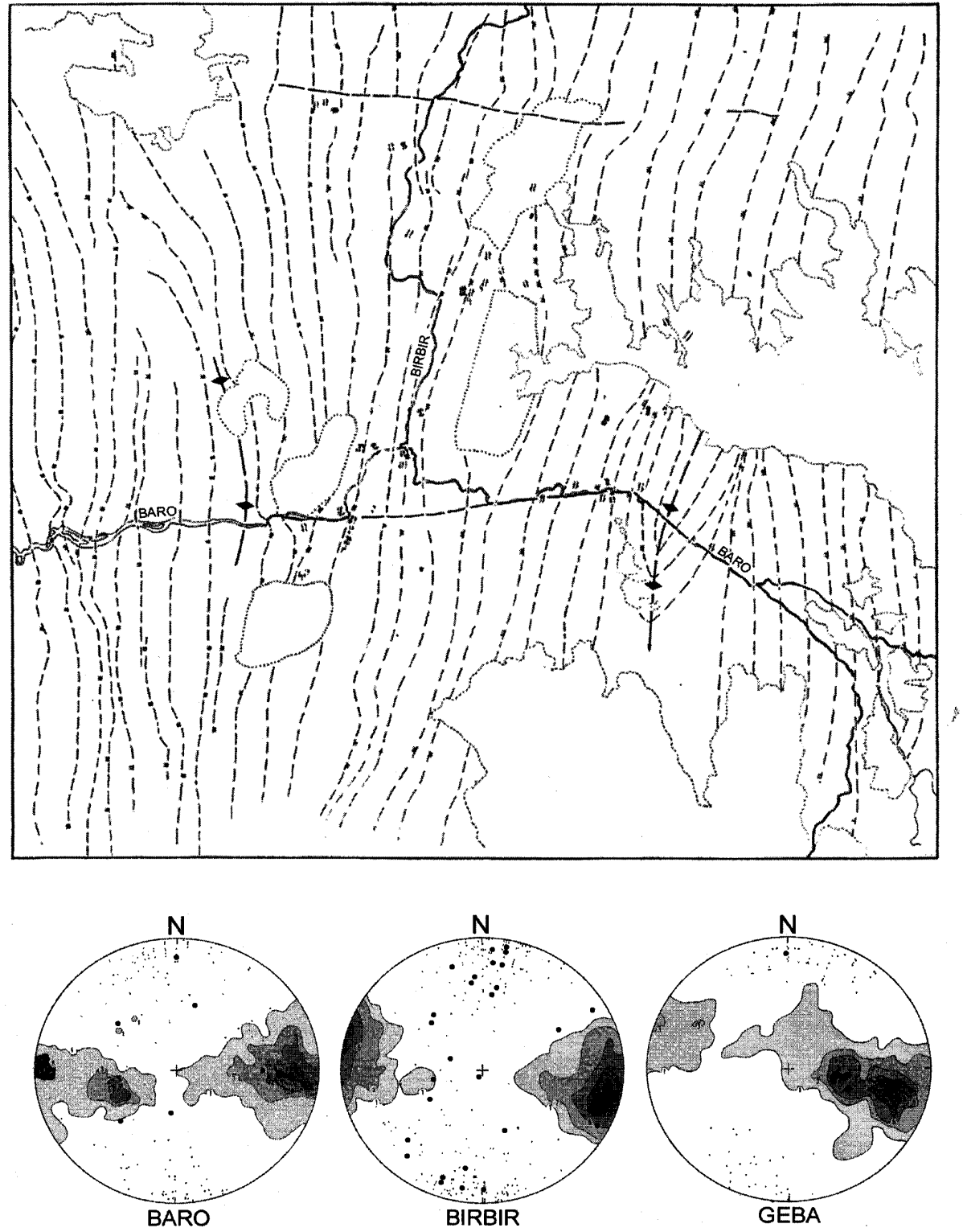

Fig. 2. (a) Foliation trends, shear sense and brittle faults in the Gore-Gambella area; heavy dotted lines mark plutons lacking penetrative foliation; light dots, boundaries of Tertiary volcanic rocks. Dip symbols: single $=0-30^{\circ}$; double $=31-60^{\circ}$; triple $=61-90^{\circ}$. Plan shear couple indicators refer to rotated bodies or S/C fabrics; those separated by a bar refer to folded or displaced dykes (open bar = felsic; closed bar = mafic); fold symbols refer to folded mylonitic foliation. Brittle faults marked by heavy dashed line; ornamented dashed lines mark major foliation antiforms in Baro and Geba domains. (b) Equal area plots of structural data by domain. Contours represent concentrations of foliation poles, as percent per $1 \%$ area. Dots= stretching lineations; $x=$ minor fold axes. Total foliation populations: $\mathrm{Baro}=296$; $\mathrm{Birbir}=519 ; \mathrm{Geba}=118$. Total lineations: Baro = 130; Birbir = 113; Geba = 80. 
The geotectonic evolution of the WES has been interpreted in terms of early rifting and associated sedimentation, followed by subduction and islandarc formation, arc-accretion and, finally, continent-continent collision (e.g., Kazmin et al., 1978). The latter stages, the Pan African orogeny, resulted from the collision of east and west Gondwana (e.g., Stern, 1994) and caused severe E-W crustal shortening. Linear belts of highly deformed maficultramafic bodies within low-grade (ANS) terrains have been interpreted as dismembered ophiolitic rocks (e.g., Kazmin et al., 1978; Warden et al., 1982; Seife Michael Berhe, 1990; Teklewold Ayalew et al., 1990; Abdelsalam and Stern, 1996) although incontrovertible evidence for this is often lacking. There is a growing body of evidence to suggest that bodies within the WES have an intrusive nature (Grenne et al., 1998; Aberra Mogessie et al., 1999) and were emplaced into an extensional back-arc rift setting (e.g., Braathen et al., 2001).

Detailed estimates of peak metamorphic conditions within the Ethiopian shield are largely lacking. Characteristic metabasite parageneses generally imply greenschist to lower-amphibolite facies within the juvenile (ANS) domains and mid- to upper-amphibolite facies in the gneissic domains. Based on metapelitic assemblages within the WES, Teklewold Ayalew (1997) deduced conditions of around $520^{\circ} \mathrm{C}$ and $4 \mathrm{kbar}$ and $700^{\circ} \mathrm{C}$ and 7 kbar for the Birbir and Baro domains, respectively, and implied a steep metamorphic gradient at the domain transition. Johnson et al. (in press) showed that the rocks encountered two major metamorphic events and followed an anticlockwise P-T-t path.

Three geochronologically constrained generations of intrusions are recognised in the area (Teklewold Ayalew et al., 1990). Pre-kinematic bodies, dated to the interval 830-810 Ma, have a mafic to intermediate calc-alkaline arc affinity and show evidence of mantle derivation (Teklewold Ayalew and Peccerillo, 1998). Begashaw Wolde (1996) argue that these early bodies formed by partial fusion of newly underplated basaltic crust. Syn-kinematic leucogranitic bodies, dated at around $780 \mathrm{Ma}$, have a peraluminous chemistry and trace-element signature suggesting derivation from anatexis of crustal metasediments (Teklewold Ayalew and Peccerillo, 1998). The 780-760 Ma interval is regarded as the age of peak-metamorphism, basin-closure and arc-accretion (Teklewold Ayalew et al., 1990). Late- to post-kinematic high-K granites, dated at c. 570-

$540 \mathrm{Ma}$, provide minimum age constraints on deformation and metamorphism in the area.

\section{GNEISSIC TERRANES}

\section{Lithology}

The easterly Geba domain is dominated by rather monotonous quartzofeldspathic gneisses. The predominant rock types are strongly foliated, medium- 
grained biotite and hornblende-biotite gneisses (big, hbg). Some of the gneisses are migmatitic and contain numerous subconcordant lenses of granitic and pegmatitic material. A uniform granitoid composition and lenticular texture over hundreds of square metres of outcrop suggest that the majority of big and $\mathbf{h b g}$ are tonalitic or granodioritic orthogneisses. Rare garnet-bearing and commonly epidotised rocks are more probably paragneisses.

Although the westerly Baro domain is similarly dominated by orthogneissic big and hbg, paragneisses characterise the eastern margin of the Baro close to the contact with the Birbir. Lithologies here include interlayered garnetsillimanite gneiss (gsg) and calc silicate gneiss (csg) with subordinate garnetamphibolite (gag) and magnetite-bearing quartzite (mqs). These rocks are of particular importance as they contain relatively low-variance assemblages suitable for thermobarometry (Johnson et al. in press). The main exposures of gsg occur near Bonga and consist of garnet and/or sillimanite-bearing biotiteplagioclase-quartz-microcline gneiss layers, up to tens of metres thick, associated with grey to pink biotite gneisses and schists. The sillimanitebearing rocks commonly contain knots, a few centimetres in diameter, of intergrown sillimanite, quartz and plagioclase (Plate $1 \mathrm{~F}$ ), and large garnet porphyroblasts. Locally, garnets up to $5 \mathrm{~cm}$ in diameter constitute as much as $60 \%$ of the rock and are intergrown with quartz, biotite and sillimanite. Cordierite-orthoamphibole (gedrite-cummingtonite)-bearing rocks are locally interlayered with the sillimanite-garnet-biotite gneisses. Calc-silicate gneisses (csg) occur along the eastern boundary of gsg. The rock is fine to medium grained, green-grey, weakly foliated and commonly layered on a centimetre scale. Mineral assemblages in these rocks include garnet-epidote-hornblendediopside, garnet-epidote-microcline-biotite and biotite-plagioclase-hornblende with epidote rich layers. Centimetre-scale clusters of sphene are common and calcite is rare. Garnet amphibolites (gag) occurring south and east of Bonga contain layers of coarse, granofelsic plagioclase-garnet-hornblende and garnet-cummingtonite/gedrite gneisses. Deep red garnet porphyroblasts reach $5 \mathrm{~cm}$ in diameter and constitute up to $40 \%$ of the rock. These are commonly surrounded by pale domains rich in cummingtonite/gedrite, plagioclase and quartz. The matrix comprises course decussate hornblende.

\section{Petrography}

Garnet-sillimanite gneiss (gsg) forms anhedral porphyroblasts up to $5 \mathrm{~mm}$ across and characterized by inclusions of rounded, unstrained quartz and randomly oriented biotite. Inclusions are concentrated within cores and rims are largely inclusion free. Many grains contain patches of finely disseminated rutile and/or small, randomly orientated muscovite. Many garnet porphyroblasts are flattened within the well-developd foliation. The matrix comprises domains dominated by either sillimanite or quartz. Sillimanite 
domains contain both fibrolite and highly elongate prismatic (up to $2 \mathrm{~mm}$ in length) varieties which, along with biotite, define the foliation. These aluminous domains commonly occur as clots, which may be several centimetres across. Quartz-rich matrix domains also contain plagioclase, biotite, garnet and prismatic sillimanite. The quartz is highly strained with sutured grain boundaries. Subgrain development is common. Plagioclase is anhedral and weakly strained. Biotite commonly occurs as isolated grains parallel to the foliation or at the margins of garnet porphyroblasts, probably as products of retrogression. Spinel forms rare, skeletal grains in contact with biotite. Chlorite may form as an alteration product after garnet.

The garnet amphibolite gneiss (gag) unit shows little evidence for any strong deformation. Garnet forms large, anhedral poikiloblasts up to $40 \mathrm{~mm}$ across. Inclusions are dominated by sub-rounded quartz and plagioclase and randomly orientated cummingtonite/gedrite. Fractures within the garnets may concentrate biotite and/or chlorite as retrogression products. The matrix comprises stubby, decussate hornblende, generally 1-2 mm across, with smaller amounts of plagioclase, biotite and quartz. Hornblende is not found in contact with garnet and the latter phase is surrounded by granoblastic patches containing quartz, plagioclase and ilmenite-magnetite or, more commonly, complex intergrowths of orthoamphibole, plagioclase and quartz. The most abundant of these are of prismatic orthoamphibole and coarse plagioclase (both up to $5 \mathrm{~mm}$ ) and intergrowths are aligned with the long-axis of the amphiboles. Less commonly, small blebs of quartz are found within plagioclase. These textures are interpreted to represent reaction between garnet and the hornblende-rich matrix.

The calc-silicate gneiss unit (csg) contain pale-brown garnets, up to $20 \mathrm{~mm}$ across and skeletal in form. These are commonly surrounded by complex vermicular overgrowths dominated by yellow epidote with calcite and quartz. In some cases, garnet alteration is near complete. Anhedral green diopside grains $(<0.5 \mathrm{~mm})$ occur in patches and are commonly associated with similarly sized magnetite. The matrix comprises an anhedral granoblastic mosaic of plagioclase, strained quartz and microcline $(0.5-1 \mathrm{~mm})$ with lesser amounts of sphene, calcite and epidote. Patches exist within the rock where alteration is pronounced. Here, garnet is epidotized, plagioclase is commonly sericitized and diopside grains show variable degrees of alteration to hornblende.

Amphibolitic gneisses (hbg) are dominanted by hornblende, biotite, epidote and sphene with a quartz-plagioclase matrix. Rare porphyroblasts of ilmenite, up to $4 \mathrm{~mm}$ across, enclose plagioclase, quartz and rarely muscovite. Anhedral hornblende is green to pale-brown pleochroic and may have inclusions of sphene, quartz and biotite. Biotite (up to $2 \mathrm{~mm}$ ), anhedral epidote (up to 0.5 
$\mathrm{mm})$ and euhedral sphene $(0.5 \mathrm{~mm})$ commonly occur with hornblende in mafic glomerocrysts. The matrix is similar to that of the biotite gneisses (big) although K-feldspar is rare and muscovite absent. Euhedral apatite is a common accessory.

The biotite gneiss unit (big) are dominated by quartz, feldspars and biotite with lesser amounts of epidote and muscovite. Garnet is only rarely encountered. Where present it forms anhedral, flattened grains, some in excess of $1 \mathrm{~cm}$ across. These are rimmed by coarse-grained, granoblastic epidote/clinozoisite and calcite. Inclusions of biotite, quartz and epidote lack any strong preferred orientation. Biotite occurs as isolated grains or, more commonly, as glomerocrystic aggregates associated with primary epidote and muscovite. Individual grains are up to $3 \mathrm{~mm}$ in length. Muscovite (up to $0.3 \mathrm{~mm}$ ) may also occur as isolated grains within the matrix. Epidote grains are anhedral to euhedral and up to $0.5 \mathrm{~mm}$ across. The quartzofeldspathic matrix has a granitic texture and a typical grain size of 1-2 mm. K-feldspar is present as both mesoperthite and microcline and rarely forms graphic intergrowth with quartz. Plagioclase is usually homogeneous but may show a weak normal zoning. Quartz exhibits a weak undulose extinction. Ilmenite, apatite and zircon are rare accessories. The fabric is generally only weakly developed within the gneisses although higher strain domains are defined by elongate biotite and recrystallized quartz and feldspars. Irregular horizons and patches rich in epidote, sphene, biotite and calcite are common and suggest some channelled influx of aqueous Ca-rich fluids.

\section{BIRBIR DOMAIN}

\section{Lithology}

The Birbir domain comprises metasedimentary rocks (mss), metavolcanics (mvs), altered subvolcanic sills and dykes and mylonitic quartz diorite (mqd). The metasediments are weakly to strongly schistose metagreywacke and pelite, with subordinate coarse volcaniclastic and carbonate rocks. Primary sedimentary features such as bedding, cross lamination, load-casts and graded bedding are common in metagreywackes. Beds up to $1 \mathrm{~m}$ thick consist of a relatively coarse massive base, containing rip-up clasts up to $20 \mathrm{~cm}$, fining upward into a laminated, pelitic top (Plate 1C). Laminations are typically convolute and/or truncated by the overlying bed. Lenses of polymictic, coarse volcaniclastic rocks (Plate $1 \mathrm{E}$ ) contain poorly-sorted, matrix-supported clasts predominantly of rhyolitic and andesitic composition. Intercalated 1-10 m thick layers of metavolcanic rocks are identified by their relative homogeneity and a uniform distribution of unbroken plagioclase phenocrysts $(0.5-3 \mathrm{~mm})$. These range from basaltic to rhyolitic in composition, but are predominantly 
intermediate. Rare amygdaloidal andesitic flows (3-4 m thick) are intercalated with metagreywacke (Plate 1D). Some tuffaceous horizons contain abundant subhedral and broken plagioclase crystals $(2-5 \mathrm{~mm})$ in a fine-grained, biotiterich matrix. Large porphyroblasts of andalusite (Plate 1C) occur with staurolite and traces of graphite and garnet occur locally in aluminous pelitic layers. Decussate andalusite overgrows the foliation and is the result of contact metamorphism. Fe- and muscovite-rich pelites contain chloritoid and staurolite ( \pm garnet and/or chlorite) which are clearly of regional metamorphic derivation. Metavolcanic rocks (mvs) are actinolite-chlorite schists. Typical assemblages contain actinolitic hornblende-plagioclaseepidote-chlorite-quartz- $( \pm$ biotite, calcite). These rocks are commonly interlayered on a centimetre to metre scale with subordinate felsic muscovitequartz-feldspar schists. Although deformation has typically obscured the contact relations of the layers, where least deformed they commonly exhibit low-angle discordance and microporphyritic textures suggesting that they were dykes. Such bodies may comprise in excess of $50 \%$ of the outcrop. Primary igneous textures include plagioclase laths and hornblende phenocrysts in rocks of andesitic composition.

Sedimentary structures within the turbidites and associated coarse volcaniclastic rocks suggest rapid deposition by sediment gravity flows close to an eroding, uplifting source. The slight rounding of clasts indicate subaerial transport and/or shoreline abrasion and imply a subaerial volcanic source area. The predominance of immature facies and the absence of sedimentary rocks of continental derivation are features similar to those of present-day, intra-oceanic island arc environments.

\section{Petrography}

Pelites (mss) are rare within the Birbir. Most comprise highly foliated Fe-Mg poor muscovite-quartz-graphite schist although biotite-rich schists are represented. Low variance assemblages best exposed near the roadside south of Ayra are charcterised by porphyroblasts of staurolite and chloritoid set within a matrix dominated by quartz, muscovite and plagioclase with small disseminated opaques. The lowest variance assemblages additionally contain garnet and/or chlorite. Staurolite is abundant and forms subhedral to anhedral sieve-textured poikiloblasts up to $1 \mathrm{~mm}$ in diameter. Chloritoid is generally present as stubby prismatic grains up to $0.5 \mathrm{~mm}$ in length and with aspect ratio of 2 or 3:1. These are commonly associated with quartz-rich strain shadows and are variably rotated into the strong muscovite- and/or graphitedefined crenulated fabric, suggesting chloritoid growth occurred pre-D2. Garnet porphyroblasts $(0.2-0.5 \mathrm{~mm})$ are variably altered to hematite along the periphery of grains and along fractures and are in many cases completely pseudomorphed. Chlorite generally forms large, irregular porphyroblasts and 
aggregates up to $2 \mathrm{~mm}$ across, although smaller disseminated matrix grains are represented. Inclusions within porphyroblast phases are dominated by small disseminated opaques, with quartz and feldspar additionally occurring within staurolite and garnet. Dusty graphite inclusions are ubiquitous within chloritoid and hourglass textures are common. Any strong alignment of inclusions is lacking. Although matrix muscovite generally defines the schistosity, some rocks are muscovite $(\mathrm{K})$ deficient, and in these the fabric ids defined by the abundant matrix chloritoid whose aspect ratios reach 5:1 or greater. Late muscovite may overgrow the schistosity and some rocks are epidotised.

Fine grained metavolcanic unit (mvs), rich in chlorite, have high variance assemblages. Chlorite is disseminated throughout the matrix but, where strongly deformed, commonly occurs in thin (0.2-0.3 $\mathrm{mm}$ thick) discontinuous layers which define the foliation and are characterised by small, irregular opaques. Chlorite domains are separated by areas rich in either fine-grained quartz and plagioclase or calcite. These contain discontinuous quartzofeldspathic veins with thicknesses up to $0.5 \mathrm{~mm}$ which preferentially concentrate euhedral to subhedral pyrite cubes $(<0.5 \mathrm{~mm})$. In addition, chlorite may form irregular aggregates up to $3 \mathrm{~mm}$ across associated with equant porphyroblasts of calcite $(0.5-1 \mathrm{~mm})$. Rarely, small irregular grains of epidote are present. The amount of muscovite within these lithologies differs reflecting a variable input of argillaceous material into the original volcano-sedimentary protoliths. Biotite and apatite are rare accessories. Actinolitic hornblende is rarely present.

\section{STRUCTURE}

The orientation of planar and linear fabrics along the Gore-Gambella transect are presented in equal area plots (Figure $2 b$ ). There is a predominantly northsouth structural grain although foliation trends diverge in the north-central part, corresponding to a widening of the Birbir domain toward the north (e.g., Kazmin et al., 1979, Figure 1 - NB. see the distribution of the volcanosedimentary terrane (VST) shown in the location map). At least four regional deformation events (D1-D4) are recognised.

\section{Gneissic terranes}

The first deformation event, D1, resulted in the formation of a subhorizontal gneissosity within the gneissic terranes which was subsequently folded by D2. 
a. Pre-accretionary: ? - 780 Ma

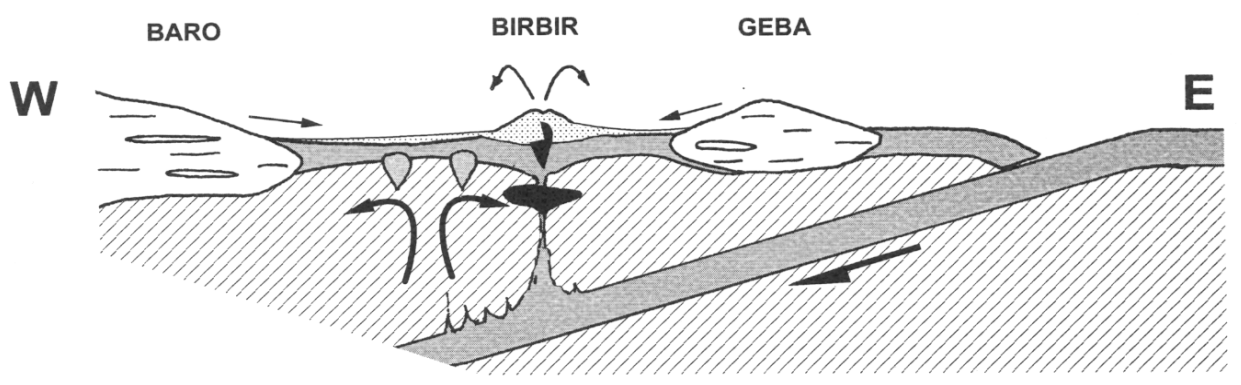

b. Accretionary (D2 shortening): 780-635 Ma

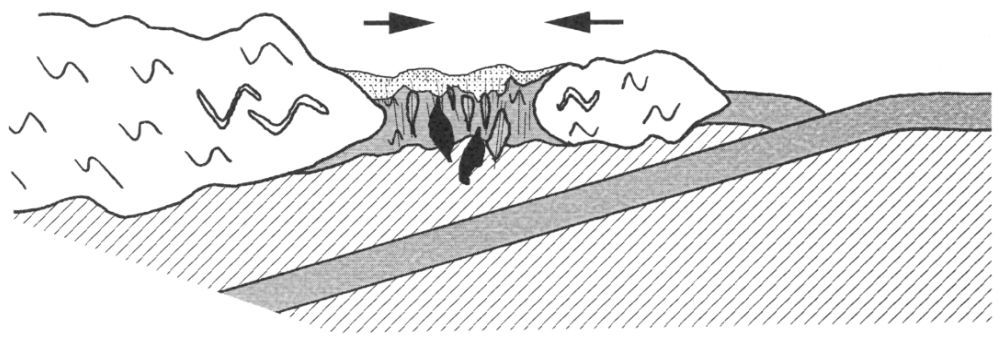

c. Accretionary (D3 transcurrent shear): 635-580 Ma

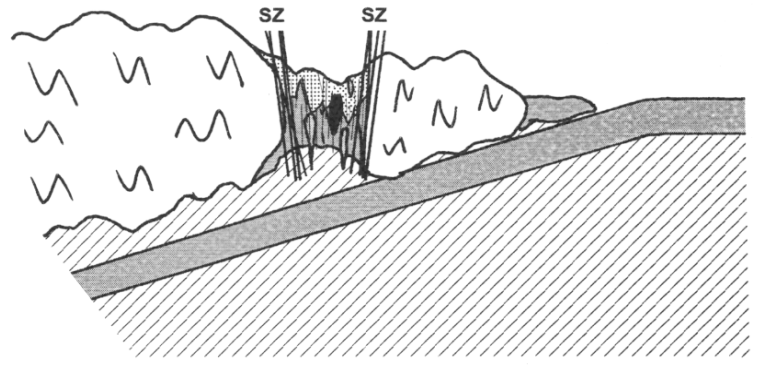

d. Cratonisation: 580-540 Ma

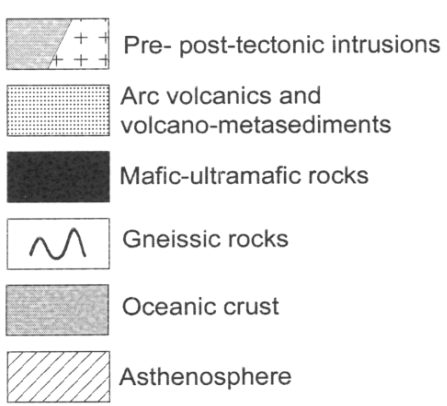

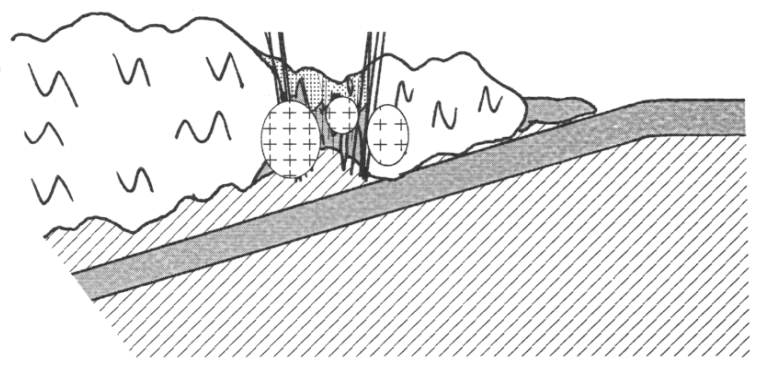

Fig. 3. Cartoon to illustrate the tectonic evolution of western Ethiopia in the late Proterozoic. 
The Geba domain shows open D2 folding of the gneissic layering (S1) around gently plunging, NNE-trending axes. Extension lineations are shallow. The foliation dips predominantly toward the west. A major antiform at the western margin of the Geba domain is truncated by rocks of the Birbir domain. The contact is marked by mylonitic metagranite sheets (mgt). Farther east of the Geba domain, beyond the map area, large-scale isoclinal recumbent folds have been identified that have east-west oriented axial surface traces (Kazmin et al., 1979; Mengesha Tefera and Seife Michael Berhe, 1987). These are deflected into a north-south trend as the boundary with the Birbir domain is approached, and show north-south folds that are superimposed on flatlying gneissic layering (Teklewold Ayalew and Moore, 1989).

The Baro domain contains planar structures with a general northerly strike and moderate dips to the east and west. The equal area plot (Fig. 2b) exhibits an incomplete foliation girdle. Linear features plunge gently north or south, except in the area immediately west of the Birbir domain (north west of Bure), where lineations plunge moderately toward the east and down the dip of foliation. Here, a fold pattern expressed by foliation is truncated. The abrupt change in foliation pattern coincides with changes in the attitudes of linear features. Intrafolial folds are locally recognized in migmatites. Foliation attitudes west of Bonga define a major antiform with a kilometre-scale wavelength and a north-south trending axial surface trace. Crenulations and weak mineral lineations are developed with gentle northerly plunges, parallel to the inferred axis of the fold. Sheets of Baro leucogranite rarely show an upright, open fold pattern. Similar granite sheets are found to the south of the area which Davidson (1983) described as having tectonic contacts related to thrusting. Undeformed granitoid pegmatites cut the main fabric of these rocks.

In summary, at least two stages of ductile deformation are recorded in the gneissic terranes. D1 is defined by a well-developed gneissic layering and penetrative mineral foliation that locally encloses intrafolial folds and may, at least in the Geba domain, be associated with the formation of east-west trending folds. Early east-west folds have not been identified in the Baro domain. A second event, D2, resulted in kilometre-scale (and smaller) folds related to east-west directed crustal shortening.

\section{Birbir domain}

Structures within the metavolcano-sedimentary Birbir domain have predominantly north-south striking foliations that dip steeply toward the west. Linear features, mainly stretching lineations defined by deformed clasts, minerals and mineral aggregates, plunge shallowly $\left(<20^{\circ}\right)$ to the north and south throughout the Birbir. Sedimentary structures such as cross-lamination and graded bedding are well preserved in the metagreywackes. Although bedding and cleavage are generally subparallel, relationships west of Bure show structural facing directions that are upwards and towards the east. Map- 
scale F2 folds were not determined although rare mesoscopic folds generally have shallowly-plunging hinges that are subparallel to the stretching lineation. Steeply-plunging folds are of later (D3) derivation and related to the mylonites. The origin of the main foliation in the Birbir domain is almost certainly related to the formation of D2 folds during east-west shortening, folds which are now largely unrecognisable due to both the complex stratigraphy and their dismemberment by synchronous and/or later shear deformation. However, the foliation may locally be the result of syntectonic recrystallization during early D3 shearing.

Mylonitic rocks, the results of intense D3 shearing, occur throughout the Birbir domain, but are especially prominent in the western half, where they are mainly concentrated in a $5 \mathrm{~km}$ wide zone lying between the Baro domain gneisses to the west, and the Birbir domain rocks to the east. This feature, the Birbir shear zone (BSZ), is a NNE-striking region of high strain consisting of numerous mylonite zones separated by less strained rocks. Dips of the mylonitic S3 foliation are typically steep to vertical. Sheared rocks have stretching lineations that plunge gently to the north or south, suggesting transcurrent movement (Teklewold Ayalew, 1997). Rocks of units mqd and mvs are most intensely mylonitized. Meta-quartz diorite (mqd) is commonly converted to augen schist exhibiting $S / C$ and shear band fabrics. The mylonitic foliation is asymmetrically folded in places. Folds vary from open to tight, with the tightest having hinges orientated closest to the stretching direction. This relationship suggests progressive rotation of the hinges during a continuous shearing event.

Syntectonic (syn-D3) folded and disrupted mafic and felsic dykes are common within the BSZ. Mafic dykes are especially well-exposed on the Baro River near the sharp bend $5 \mathrm{~km}$ downstream from its junction with the Birbir River, where they display widely varying degrees of deformation. Less-deformed dykes cut earlier, more strongly foliated and dismembered examples, suggesting that they were emplaced synchronously with D3 shearing. On the western boundary, abundant mafic dykes, up to $1 \mathrm{~m}$ wide, syntectonically intrude the mylonite and preserve a complete range of finite strain increments from which the kinematics of the deformation may be deduced. Most mafic dykes were emplaced in a plane oriented $15^{\circ}$ clockwise to the mylonite foliation. These are shortened by contractional faults producing lozengeshaped fragments. A relatively small number $(10 \%)$ intrude in a plane $15-25^{\circ}$ anticlockwise from the mylonite foliation. These exhibit symmetrical boudinage. A small volume of syntectonic quartz diorite veins show identical relationships. Veins emplaced within the mylonite foliation, and rare veins emplaced normal to S3, are folded. The array of veins describe quadrants of instantaneous shortening and extension, asymmetrically disposed with respect to S3 and indicative of dextral shear combined with shortening across the shear plane. Late quartz diorite veins, symmetrically conjugate with respect to S3, are asymmetrically folded such that the combined deduced vein- 
parallel shear is the product of mainly pure shear, whose principal shortening direction is normal to the mylonitic foliation (see Teklewold Ayalew, 1997). The resulting gneissic rock superficially (albeit erroneously) resembles a foliated agmatite of quartz diorite injected into and containing flattened asymmetrical lozenges of amphibolite.

Kinematic indicators suggest a combination of both dextral and sinistral shear within the BSZ. Dextral shear sense indicators are provided by deformed mafic dykes which were intruded syn-D3. A sinistral sense of movement is shown by the displacement of late felsic dykes that clearly cut S3, rotated feldspar augen shear bands and F3 folds (see Teklewold Ayalew, 1997). The BSZ, therefore, shows early dextral movement but was subsequently reactivated to sinistral movement late in the strain history. Evidence from the Birbir shear zone suggests that the discrete terranes in western Ethiopia were developed during synchronous, transcurrent shear and igneous intrusion along the margins of continental microplates.

Numerous late D4 shear zones, predominantly northwest-southeast trending, are recognizable within the WES. These clearly offset bedrock contacts and/or are commonly occupied by brecciated zones. Where indicated, movement is primarily dextral strike-slip with stratigraphical offsets suggesting large (100 $\mathrm{m}$ - several $\mathrm{km}$ ) displacements.

In summary, four deformation events are recorded within the WES. D1 resulted in the development of a subhorizontal gneissosity in the gneissic terranes. No evidence for D1 is preserved within the Birbir rocks. D2, present in all domains, formed following east-west shortening of the region. D3 shear zones are abundant within the Birbir domain and concentrated at its margins. The relatively long lived shear zones preserve evidence for strong transcurrent movement and reactivation. D4 occurred much later (post Pan-African) and resulted in the formation of large northwest-southeast oriented brittle structures.

\section{METAMORPHISM AND P-T-T-FLUID CONSTRAINTS}

Two episodes of metamorphism affected rocks of the WES. The first, relatively high-temperature event, M1, resulted in the development of anatectic migmatites within felsic orthogneisses. Upper amphibolite facies assemblages within lower variance rocks, particularly the paragneissic units within the Baro, allow peak conditions to be constrained to around $600-800^{\circ} \mathrm{C}$ and $5-8$ kbar here. Similar metamorphic conditions to those of the Baro are calculated for the Geba, suggesting that these two discrete domains followed a similar pre- to syn-M1 tectonothermal evolution. Several structural and textural relationships show that the M1 peak occurred early relative to the development of the major structures - i) the migmatitic leucosomes are parallel to (and probably synchronous with) the S1 gneissosity. These 
leucosomes were subsequently folded by the D2 event; ii) garnets within paragneissic units are clearly flattened within the dominant (S2) foliation, and; iii) there is no strong alignment of included phases within garnet poikiloblasts. Rounded quartz inclusions are unstrained whereas matrix quartz exhibits subgrain development.

The second event, M2, is most clearly evident in garnet-bearing gneissic rocks. Many garnets are surrounded by reaction coronas dominated by epidote $( \pm$ calcite). In places, replacement is complete. Epidotisation of garnet is also evident within the calc-silicates of the Geba where, in addition, hornblende is common as a replacement product after diopside. Such features imply that M2 was both a lower temperature event and that aqueous fluids were available at or around the peak of M2 metamorphism.

Within the Birbir domain, metamorphic conditions are less easy to accurately quantify owing to the lack of suitable assemblages. However, the overwhelming abundance of chlorite-rich ( \pm talc, muscovite) rocks within the Birbir imply that greenschist-facies P-T conditions were the maximum attained within the majority of this domain. The thick clastic sequence exposed around Ayra constrains peak P-T conditions to $570 \pm 11^{\circ} \mathrm{C}$ and $8.6 \pm$ 2.2 kbar. Such sequences, poor in volcanogenic material, are untypical of the Birbir suggesting that this sequence may have been close to the stratigraphical base of the Birbir. Consequently, the conditions here should be considered as a maximum for the Birbir domain. Porphyroblast-matrix relationships within Birbir rocks suggest many of the relatively high-T parageneses (such as those at Ayra) were developed during the early (M1) event. The majority of the domain evidently suffered (D3) shear-zone-channelled fluid influx which caused isotopic resetting. Hornblende and biotite may overgrow the mylonite fabric suggesting that the M2 metamorphic peak within the BSZ occurred postD3.

M1 peak metamorphic conditions within the gneissic Geba and Baro domains were clearly higher than those recorded by the Birbir and a steep metamorphic transition is implied at domain boundaries. Such a conclusion is supported by the highly sheared (tectonic) nature of these contacts (Teklewold Ayalew, 1997). The implication is that the Birbir is unlikely to have been in stratigraphical continuity with the gneissic domains and that domains were tectonically transported to their current positions prior to, or synchronous with, M2. Johnson et al. (2002 - in press) provide a detailed treatment of the metamorphic evolution of the area. 

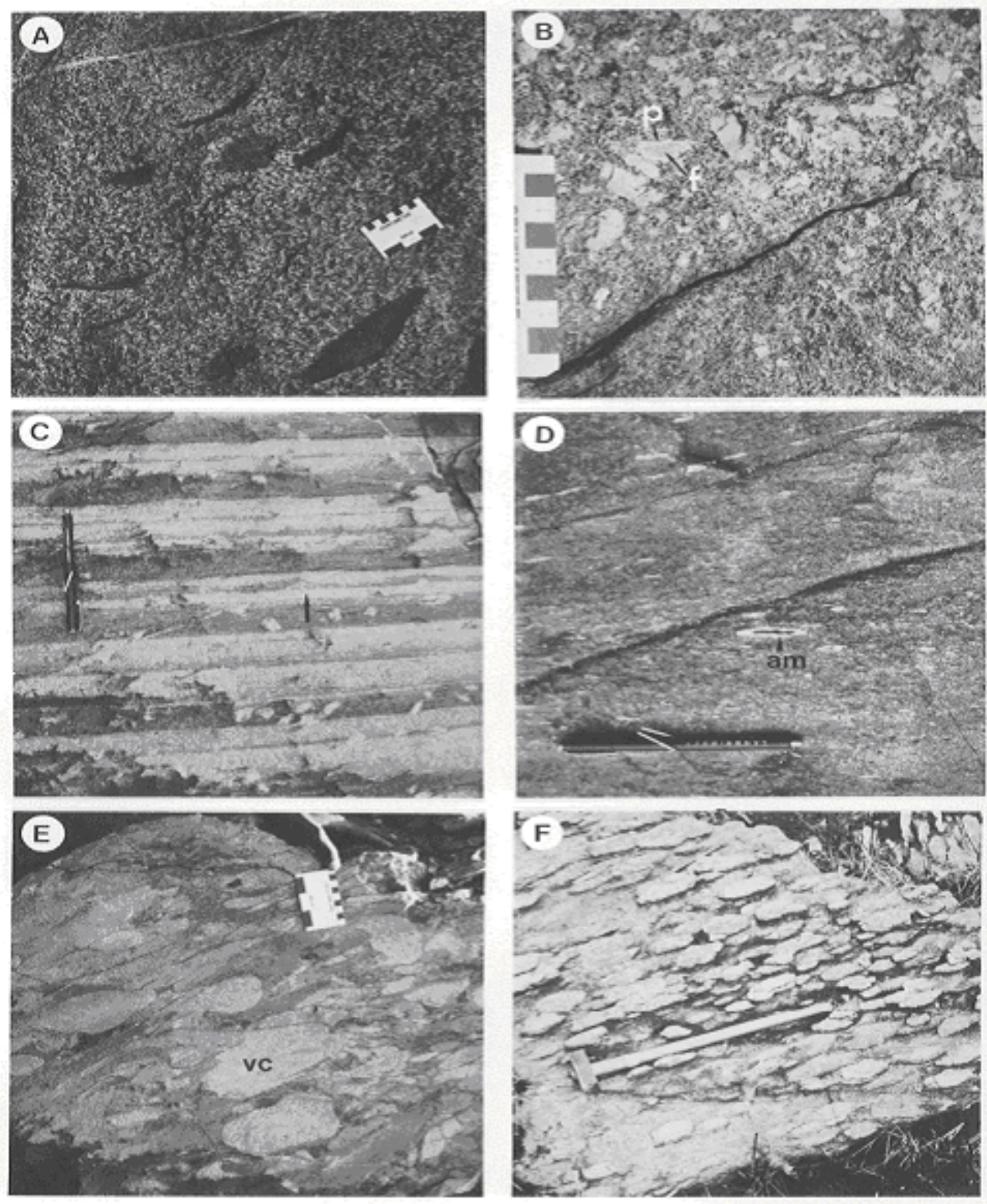

Plate 1 Structural features of rocks from the Birbir and Baro domains. A) Mafic xenoliths in Birbir quartz diorite (mqd). Main road, $10 \mathrm{~km}$ E of Bonga (see Geological Map). Small divisions on scale card are centimetres; B) Rapakivi texture in post-kinematic quartz monzonite, core of Bonga pluton

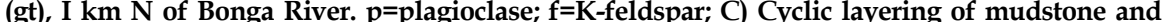
wacke in unit (mss), showing graded bedding and truncated cross-laminae. Top is shown by arrow; large andalusite porphyroblasts have grown in pelitic layers. There is a weak cleavage of $25^{\circ}$ to the bedding. One kilometre $\mathrm{N}$ of main road, $11 \mathrm{~km} \mathrm{~W}$ of Bure. Pen magnet is $12 \mathrm{~cm}$ long; D) Andesite flow in (mss), containing flattened quartz amygdules (am), two kilometres $\mathbf{N}$ of main road, $10 \mathrm{~km} \mathrm{~W}$ of Bure; F) Coarse volcaniclastic rock (mss), viewed on surface perpendicular to lineation. vc-flow banded rhyolite clast. Main road, $9 \mathrm{~km} \mathrm{~W}$ of Bure; F) Sillimanite-quartz nodules in (gsg) near the eastern boundary of the Baro domain. Hammer handle, $50 \mathrm{~cm}$ long, lies on foliation plane and parallel to shallowly-plunging lineation. Three kilometres north of Baro River, 2 km N of Bonga. 


\section{PETROCHEMISTRY OF IGNEOUS ROCKS}

Major and trace element data from magmatic rocks from the WES have been used to infer their petrogenetic history and the tectonic environment in which the magmas were emplaced (Teklewold Ayalew et al., 1987; Teklewold Ayalew and Peccerillo 1998; Grenne et al., 1998; Tadesse Kebede et al., 1999; Aberra Mogessie et al., 1999; Braathen et al., 2001; Tadesse Kebede et al., 2001; Tadesse Kebede and Koeberl, 2002). In the Gore-Gambella transect, pre- to syn-kinematic intrusions consist of calc-alkaline and arc-tholeiitic rocks that were generated by multistage, probably polybaric, fractional crystallization of mantle-derived parental magmas. Some of the syntectonic granites are interpreted as melts derived by anatexis of crustal rocks during the peak of metamorphism in the Baro domain. The late- to post-kinematic plutons are slightly more enriched in $\mathrm{K}$ and are characterised by incompatible trace element compositions which are intermediate between typical subductionrelated and intraplate granitoids. Elemental variations suggest a shoshonitic chemical affinity that is probably related to the melting of calc-alkaline continental crust, followed by fractional crystallization and assimilation (Pearce, 1982).

The volcanic rocks from the Birbir domain constitute relatively uniform layers a few metres or more in thickness. Most exhibit relict (primarily plagioclase) phenocrysts - relict amygdales are rare. The chemical data demonstrate less coherence than in the case of the plutonic rocks, but suggest that the volcanic rocks are predominantly subalkaline andesites varying from basalt to rhyolite. A typical calc-alkaline trend is exhibited, similar to that shown by the intermediate plutons. The volcanics have low values of high field strength elements such as $\mathrm{Ti}, \mathrm{Zr}, \mathrm{Nb}$ and $\mathrm{Y}$, typical of subalkaline, island arc volcanic rocks (Pearce, 1982). These elements are considered less mobile and show little scatter, allowing classification of the basalts and basaltic andesites as calcalkaline, arc volcanics (Mengist Teklay, 1986; Teklewold Ayalew and Moore, 1989). MORB-normalized profiles for the basalts and basaltic andesites, as well as $\mathrm{Zr}-\mathrm{Nb}$ relations in the more felsic rocks, suggest a high-K calc-alkaline affinity for the whole suite, similar to those within oceanic arcs (Pearce, 1982).

In summary, the meta-igneous rocks of the Birbir domain are dominantly subalkaline and show the chemical characteristics of magmatic arc products such as those associated with present-day subduction zones. The most "primitive" plutonic rocks have a chemistry suggesting oceanic affinity. Both the intermediate plutons and the volcanics they intrude are calc-alkaline and similar to rocks found in island arcs. The intercalation of turbiditic sediments with lavas indicates that the latter were deposited subaqueously. The association of thin carbonates suggests a marine environment. The Baro metagranitic rocks have peraluminous affinities that, together with their high 
metamorphic grade and close association with aluminous metasediments, suggest they were derived by partial melting of continental crust.

\section{Geochronology}

According to the works of Teklewold Ayalew et al. (1990), nearly concordant zircons of igneous origin give precise intrusion ages for the pre-kinematic Birbir quartz diorite and Goma granodiorite, of $828+9 /-2 \mathrm{Ma}$ and $814 \pm 2 \mathrm{Ma}$, respectively, representing the earliest known igneous activity in the Birbir domain. Zircons from Baro domain leucogranites yield an array of discordant data points that are remarkably linear, where the upper and lower intercepts correspond, respectively, to ages of $783+19 /-14 \mathrm{Ma}$ and $582+29 /-33$ Ma. Scanning electron micrographs show a complex internal morphology, comprising euhedral, zoned cores and metamorphic overgrowths. The line on the concordia plot was interpreted as a mixing line between the two generations of zircon. These dates are thought to represent, respectively - i) the age of syntectonic intrusion of an anatectic melt, and, consequently, the age of an early, high-T metamorphic event (M1) and; ii) the time of a second, distinctly later, regional metamorphic event (M2).

The late-tectonic Mao granite cuts the main mylonitic fabric of the BSZ but is itself marginally deformed. Five zircon size fractions yielded a concordia with an upper intercept of $772+70 /-63 \mathrm{Ma}$ and the lower intercept to a date of 541 +10/-16 Ma. Scanning electron micrographs show zircons containing cores with dark inclusions (probably hematite), mantled by well-developed igneous zoning. The data points trend away from concordia and thus appear to define a mixing line between pre-intrusion inherited zircon cores and predominant igneous overgrowths. The data points that plot close the lower intersection are considered relatively free of inherited zircon and, consequently, the lower intercept is interpreted as the time of intrusion. The poorly constrained upper intercept indicates the age of growth of inherited zircons. These may have been generated synchronously with the formation of the Baro leucogranites. Quartz monzonite of the Bonga pluton, which intrudes across the boundary zone of the Birbir and Baro domains, contains near concordant zircons yielding ages of $571+11 /-3 \mathrm{Ma}$. This, together with the age of intrusion of the Mao granite, constrains the termination of tectonic and intrusive activity to $c a$ .580-570 Ma and ca. 550-525 Ma, respectively. The pre-kinematic Birbir quartz diorites also yielded a $\mathrm{Rb}-\mathrm{Sr}$ isochron date of $632+/-8 \mathrm{Ma}$, with ${ }^{87} \mathrm{Sr} /{ }^{86} \mathrm{Sr}$ ratio intercepts of $0.70368+/-0.0003$. As this date is much lower than the age of intrusion estimated from the U-Pb zircon data, it is thought to reflect a time of isotopic rehomogenization, probably resulting from shearing and associated fluid influx. 
Three ages of plutonism are thus identified in the WES, at $c a$. 835-810, 800-770 and 580-525 Ma. The earliest plutons have intruded the sedimentary succession of the Birbir domain that are of unknown age, but the lithology of the clastics suggests affinity with calc-alkaline volcanism that was probably coeval with early plutonism. Initial ${ }^{87} \mathrm{Sr} /{ }^{86} \mathrm{Sr}$ ratios for the Birbir calc-alkaline suite $(<0.7040)$ indicate that they are unlikely to have been derived from crustal sources. Emplacement of the Baro leucogranite denotes a high-grade regional metamorphic event (M1) at ca. 800-770 Ma. Metamorphism took place in the Birbir shear zone at ca. 640-620 Ma and in the eastern Baro domain at 610-550 Ma. Deformation and metamorphism in the WES had ceased by $c a$. 550 Ma.

\section{DISCUSSION}

The Baro and Geba domains are characterized by blocks consisting of heterogeneous, medium to coarse grained ortho- and paragneisses, and migmatites that show no evidence of primary sedimentary or volcanic features. For the most part they lack muscovite; sillimanite and almandine garnet are present in aluminous rocks and clinopyroxene accompanies darkcoloured hornblende in mafic rocks. The metamorphic orthopyroxene and dark quartz and feldspars that are characteristic of granulite facies have not been observed in the area. The age of formation of the gneisses in the Baro and Geba domains is unknown. Although commonly thought to be older than the volcano-sedimentary terranes, few rocks older than Neoproterozoic have been conclusively identified.

Rocks of the Birbir domain are typically fine grained schists, that locally exhibit fine-scale sedimentary and volcanic structures. Muscovite is abundant in rocks of suitable composition, chlorite was locally stable and plagioclase is albitic even in mafic rocks. In some of the plutonic bodies, primary textures are preserved that involve high temperature minerals such as pyroxene and calcic plagioclase (Teklewold Ayalew and Peccerillo, 1998). Where recrystallization is extensive, the plutons exhibit mylonitic textures and comprise assemblages similar to those of the enclosing schists. These features are all indicative of a lower regional metamorphic grade than the adjacent domains. In addition, the Birbir domain rock associations appear to be distinct not only in metamorphic grade, but also in protolith types, from the Baro and Geba gneisses.

Rocks of the Birbir domain are sheared throughout and also bounded by tectonites. The western margin of the Birbir domain contains a major shear zone; the eastern boundary is also marked by mylonite and by truncation of foliation patterns that define a map-scale antiform in the Geba domain (Figure 
2a). Deformation within the Birbir domain has produced penetrative foliation and schistosity that runs subparallel to those of the enclosing gneissic terranes. An apparently coeval regional deformation thus appears to have affected rocks of both the Baro and Geba high-grade gneissic terranes and the Birbir lower-grade terrane.

The change in metamorphic grade is observed in samples obtained within strike-normal distances of 1-4 km, suggesting abrupt increase in metamorphic grade across the domain boundaries of the Birbir domain (Teklewold Ayalew, 1997). The metamorphic gradient is probably too steep to be accounted for by exposure of more deeply buried rocks by tilting, and there are no faults in the area that appear to have major vertical displacements. The gneissic domains thus appear to have been tectonically juxtaposed.

Older east-west oriented folds documented in gneisses of the Geba valley (Mengesha Teferra and Seife Michael Berhe, 1987) have not been observed in the Baro domain. Along the north-west frontier between Ethiopia and the Sudan, however, Warden and Horkel (1984) identified east-west trending folds from satellite imagery. There is little evidence to correlate the Baro and Geba domains, but the presence in both of more than one generation of deformation, similar grade of metamorphism and their tectonic relationship with the lower-grade rocks all suggest that both are composed of reworked rocks, possibly pre-Pan-African in age. Intense deformation along north-south Pan-African structures coupled with recrystallisation may have obliterated any earlier metamorphic features.

The altered ultramafic masses and associated rocks that form an array in the WES, such as the Tulu Dimtu - Daleti - Tulu Kapi - Yubdo belt, because of their narrow linear nature are considered as dismembered ophiolites that represent convergent boundaries or suture zones between continental and island arc terrane (Kazmin et al., 1979, de Wit and Senbeto Chewaka, 1981; Vail, 1985; Seife Michael Berhe, 1990; Abdelselam and Stern, 1996). Braathen et al. (2001), however, suggested that the altered ultramafic masses were originally formed as intrusions along one or more propagating rift axis within the arc complex. Although intrusive contacts are not observed, strong shearing characterize their contacts with marble and other sediments, which is attributed to significant contrast in competence. In addition, magmatic layering and lamination, and a variety of coeval mafic dykes in the associated gabbroic bodies. 


\section{RELATIONSHIPS OF THE DOMAINS}

Rocks of the Birbir domain can be traced northward into the volcanosedimentary terranes of the Pan-African southern Red Sea Hills of the Sudan. The lithology is typical of arcs arising from subduction. The Birbir calcalkaline suite has a chemical and isotopic signature indicative of an oceanic origin. The southern part of the Birbir domain, the Akobo domain of Davidson (1983), contain lenses of altered ultramafic rocks. These features collectively support the contention that old continental crust does not extend beneath the Birbir domain, and that its magmatic history is associated with a cycle of ocean opening and closure. The progressive narrowing of the Birbir domain southward may result from either or both of primary variation in the width of an ocean basin, or the amount of crustal shortening during closure. Rocks of the Geba domain can be traced southward through the Hamar domain of Davidson (1983) and thence into the Mozambique Belt rocks of NW Kenya. Although the Baro domain cannot be directly linked to the Mozambique Belt in this manner, its lithologic features are sufficiently similar to suggest such a correlation.

There is as yet no geochronological evidence to support the view that rocks of the Baro and Geba domains are older than those of the Birbir domain. Rocks from areas to the west of the Mozambique Belt, relatively unaffected by the Pan-African event, have yielded ages of 2900 and 2000 Ma for the Dodoman system in the Tanzanian craton (Bell and Dodson, 1981) and around $1900 \mathrm{Ma}$ for the Ubendian-Usagaran fold belt (Gabert, 1984). Zircons from gneisses in eastern Egypt have yielded $2600 \mathrm{Ma}$ (Klerkx and Deutsch, 1977), $1700 \mathrm{Ma}$ (Dixon, 1981) and $1149 \mathrm{Ma}$ (Loizenbauer et al., 2001). Nd isotope studies of peraluminous granites from NW Kenya suggest crustal precursors older than $1650 \mathrm{Ma}$ (Harris et al., 1984), whereas nearby lower grade Pan-African rocks have younger model ages and mantle signatures with no suggestion of crustal origin.

The ages obtained by Teklewold Ayalew et al. (1990) and Johnson et al. (in press) demonstrate that part of the plutonic and metamorphic evolution of the Baro domain is synchronous with that of the Birbir domain. At least two distinct metamorphic events, with ages of $c a$. 800-780 Ma and 635-580 Ma have affected all domains. The only relatively mature metaclastic rocks, garnetamphibole gneiss (gag), garnet-sillimanite gneiss (gsg) and calc-silicate gneiss (csg) are near the boundary between the Birbir and the Baro domains (Teklewold Ayalew, 1997). The eastern part of the Baro domain contains granites that appear to have been derived from a sedimentary source. The paragneisses of the Baro may represent a continental shelf that was tectonically reworked in the foreland of the Mozambique belt. Kröner (1977) and Loizenbauer et al. (2001) similarly regarded the gneissic terranes in Egypt 
and Sudan as having undergone transformation from a passive continental margin into a tectonically active belt that was overthrust by magmatic arc and ophiolitic rocks from the east.

The western part of the Birbir domain consists largely of plutonic and volcanic rocks with the chemical signatures of an active rifted continental margin. Farther east in this domain there are plutons with chemical characters attributable to an arc or back-arc setting (Teklewold Ayalew and Peccerillo, 1998). Both boundaries of the Birbir domain are highly tectonized and exhibit relatively steep metamorphic gradients. There is evidence of extreme flattening and shear strain. These features are consistent with the oblique accretion of a magmatic arc complex (Birbir) and a microcontinental fragment (Geba) to the foreland (Baro) terrane.

\section{GEOTECTONIC MODEL}

Possible origins for the observed patterns will be considered and a regional tectonic model proposed that is consistent with observations and current ideas of plate tectonics. The tectonic history of the western Ethiopian shield can be described in terms of the assembly of East and West Gondwanaland during the Neoproterozoic East African Orogen. There is adequate evidence for development of an arc and back-arc rift setting and/or marginal basin with subsequent terrane juxtaposition along a major shear zone. The nature of timing of the first stage is well constrained from $\mathrm{U}-\mathrm{Pb}$ and $\mathrm{Rb}-\mathrm{Sr}$ data from plutonic rocks; the proposed evolutionary model can be divided into three periods: a) pre-accretionary, b) accretionary and c) cratonization.

The pre-accretionary period started before ca. $830 \mathrm{Ma}$ and involved formation of an oceanic island arc or marginal basin, in which the low-K plutonic suite of the Birbir domain was generated. This coincides with the break-up of Rodinia at ca. $800 \mathrm{Ma}$ (see Loizenbauer et al., 2001). Back-arc spreading caused asthenospheric upwelling, M1 metamorphism and the formation of the S1 gneissosity within the Baro and Geba domains at ca. 800 Ma. Mantle-derived mafic/ultramafic magmas may have been emplaced into the Birbir at this stage. These potentially acted as the sources for the abundant subvolcanic and subaerial volcanism. It should be noted that the westerly-dipping subduction zone shown in the model is conjectural, based on the westward tectonic transport suggested by de Wit and Senbeto Chewaka (1981).

The accretionary period began with the generation of medium-K calc-alkaline arc deposits near or on the continental margin. East-west directed convergence caused D2 folding and the development of a strong S2 schistosity in the Birbir domain. Convergence was converted to D3 transcurrent 
movement and associated fluid influx along the Birbir shear zone (Teklewold Ayalew et al. 1990, Teklewold Ayalew, 1997) or its northward continuation, the Baruda-Tulu Dimtu shear belt (Braathen et al., 2001), that continued until about 635 Ma. Ultimately, there was a collision between a continental fragment, the Geba domain, and the amalgamated arc and proto-continental margin of the Birbir and Baro domains. An alternative interpretation of the mafic-ultramafic bodies of the Tulu Dimtu-Daleti-Tulu Kapi-Yubdo belt involves subducting oceanic lithosphere potentially delaminated and obducted on to the Geba domain margin which is marginally sheared and serpentinized along west-dipping fault planes (Kazmin et al., 1979). The absence of well-defined accretionary prisms, melange, and high pressure metamorphic assemblages led Braathen et al. (2001) to question the validity of the suture zone model. It is suggested that the large altered mafic-ultramafic masses were originally formed as intrusions (Aberra Mogessie et al., 1999, Braathen et al., 2001).

The cratonization period began after $635 \mathrm{Ma}$ with igneous emplacement and regional metamorphism across the sutured boundary. The little-deformed or metamorphosed mafic bodies in the Birbir domain near this boundary may be tentatively viewed, in the absence of chemical or chronologic data, as latetectonic intrusions formed in a back-arc rifting environment. Similar rocks have been reported in the northern part of the western Ethiopian shield by Braathen et al. (2001). Cratonization included emplacement of late- and posttectonic granites as well as reactivation of shear zones, minor reorganization of the accreted terranes, uplift and erosion.

The magmatic, metamorphic, structural and geochronologic data from the WES (Mengist Teklay, 1986; Moore et al., 1987; Teklewold Ayalew et al., 1987; Teklewold Ayalew et al., 1990; Teklewold Ayalew, 1997; Teklewold Ayalew and Peccerillo, 1998; Grenne et al., 1998; Tadesse Kebede et al., 2001; Braathen et al., 2001) indicate the close association of oceanic crust and the absence of thick, older continental crust in the region at the time. It is not, however, certain whether the arc rocks were entirely oceanic or whether they developed on a thinned continental margin. Syntectonic granitic plutonism in the Baro domain at ca. 800-770 Ma and a thermal event in the Birbir domain close to the same time imply arc accretion at a continental margin, consistent with a widespread regional metamorphism. The Birbir-Baro domain boundary records fluid driven metamorphism coinciding with transcurrent displacement during a period that ended $c a .635 \mathrm{Ma}$. A culminating event at about $580 \mathrm{Ma}$ generated regional metamorphism and granitic plutonism during 580-540 Ma, not only in the WES but also in the rest of the ArabianNubian shield. 


\section{CONCLUSIONS}

The tectonic history of the WES is consistent with the Pan-African evolution determined elsewhere in the Arabian-Nubian shield. The model suggested here is not one of intracontinental orogeny but rather of plate convergence involving arc accretion and ocean closure. To date there are no data that establish the original age and source of the high-grade metamorphic rocks seen in the Baro and Geba domains and elsewhere in the WES. Some of the gneisses are inliers within a wide volcano-sedimentary terrane. These are interpreted as remnants of pre-Pan-African microcontinents, representing exotic terranes accreted by oblique collision and strike-slip translation. These rocks appear to be continental crust to which the arc assemblages have been accreted.

\section{REFERENCES}

1. Abdelsalam, M.G. and Stern, R.J. (1996). Sutures and shear zones in the ArabianNubian Shield. J. African Earth Sci. 23:289-310.

2. Aberra Mogessie, Kebede Belete, Hoinkes, G., and Ettinger, K. (1999). Platinum mineralization in the Yubdo ultramafic rocks, western Ethiopia. In: Mineral Deposits: Process to Processing, Vol. 1, pp. 751-754, (Stanley et al., ed.) A.A. Balkema, Rotterdam.

3. Begashaw Wolde (1996). Tonalite-trondhjemite-granite genesis by partial melting of newly underplated basaltic crust: an example from the Neoproterozoic Birbir magmatic arc, western Ethiopia. Precambrian Research 76:3-14.

4. Bell, K. and Dodson, M.H. (1981). The geochronology of the Tanzanian Shield. Journal of Geology 89:109-128.

5. Bonavia, F.F. and Chrowicz, J. (1993). Northward expulsion of the Pan African of northeast Africa guided by a reentrant zone of the Tanzanian craton. Geology 20:1023-1026.

6. Braathen, A., Grenne, T., Masresha Gebreselassie and Tadesse Worku (2001). Juxtaposition of Neoproterozoic units along the Baruda-Tulu Dimtu shear-belt in the East African Orogen of western Ethiopia. Precambrian Research 107:215-234.

7. Davidson, A. (1983). The Omo River Project: reconnaissance geology and geochemistry of parts of Illubabaor, Kefa, Gemu Gofa and Sidamo, Ethiopia. Ethiopian Institute of Geological Surveys Bulletin 2: 89.

8. de Wit, M.J. and Senbeto Chewaka (1981). Plate tectonic evolution of Ethiopia and the origin of itsmineral deposits: An overview. In: Plate Tectonics and Metallogenesis: Some guidelines to Ethiopian Mineral Deposits, Bulletin 2, pp. 115-119. Ethiopian Institute of Geological Surveys.

9. Dixon, T.H. (1981). Age and chemical characteristics of some pre-Pan African rocks in the Arabian Shield. Precambrian Research 14:119-133.

10. Gabert, G. (1984). Structural-lithologic units of Proterozoic rocks in East Africa, their base, cover and mineralization. In:African Geology. pp. 11-22, (Klerkx, J. and Michot, J., eds). A.A. Balkema, Rotterdam. 
11. Grenne, T., Braathen, A., Mulugeta Gebreselassie and Tadesse Worku (1998). Results and models from fieldwork in the Meso-Neoproterozoic belt of western Ethiopia: the Wembera-Baruda-Bulen-Kilaj transect of the Metekel zone. Norges Geologiske Undersokelse Report 98.

12. Harris, N.B.W., Hawkesworth, C.J. and Ries, A.C. (1984). Crustal evolution in north-east and east Africa from model Nd ages. Nature 309:773-776.

13. Johnson, T.E., Teklewold Ayalew, Kruger, F.J., Poujol, M. and Aberra Mogessie (2002). Metamorphism of the western Ethiopian Shield. Precambrian Research. (In press).

14. Kazmin, V., Alemu Shiferaw and Tilahun Balcha (1978). The Ethiopian basement: stratigraphy and possible manner of evolution. Geologische Rundschau 67 (2):531-546.

15. Kazmin, V., Mengesha Tefera, Seife Michael Berhe and Senbeto Chewaka (1979). Precambrian structure and metallogeny of western Ethiopia. Annals, Geological Survey of Egypt 9:1-18.

16. Klerkx, J. and Deutsch, S. (1977). Resutats prӨlimnaires obtenus par la methode $\mathrm{Rb} / \mathrm{Sr}$ sur láge des formations precambriennes de la region d'Uweinat (Libya). Rapport Annuel. Mus७e Royal de l'Afrique Centrale.

17. Kröner, A. (1977). Precambrian mobile belts of southern and eastern Africa ancient sutures or sites of ensialic mobility? A case for crustal evolution towards plate tectonics. Tectonophysics 40:101-135.

18. Kröner, A. (1985). Ophiolites and the evolution of tectonic boundaries in the late Proterozoic Arabian-Nubian Shield of northeastern Africa and Arabia. Precambrian Research 27:277-300.

19. Kröner, A., Linnebacher, P., Stern, R.J., Reischmann, T., Manton, W., and Hussein, I.M. (1991). Evolution of Pan-African island arc assemblages in the southern Red Sea Hills, and southwestern Arabia as exemplified by geochemistry and geochronology. Precambrian Research 53:99-118.

20. Loizenbauer, J., Wallbrecher, E., Fritz, H., Neumayr, P., Khudeir, A.A. and Kloetzli, U., (2001). Structural geology, single zircon ages and fluid inclusion studies of the Meatiq metamorphic core complex: Implications for Neoproterozoic tectonics in the Eastern Desert of Egypt. Precambrian Research 110:357-383.

21. Mengesha Tefera and Seife Michael Berhe (1987). Geology of sheet NC, 36-16, (Gore sheet). Ethiopian Institute of Geological Surveys. Unpublished manuscript.

22. Mengist Teklay (1986). Petrology and geochemistry of supracrustal and intrusive rocks from the Birbir Domain of the Gore-Gambela Geotraverse. Unpublished MSc thesis. Addis Ababa University, 102 pp.

23. Moore, J.M., Morgan, J., Mengesha Tefera and Mengist Teklay (1987). Geology of the Gore-Gambella geotraverse, western Ethiopia. In: Current Research in African Earth Sciences, pp.109-112. A.A. Balkema, Rotterdam.

24. Pearce, J.A. (1982). Trace element characteristics of lavas from destructive plate boundaries. In: Orogenic Andesites and Related Rocks, pp. 525-548, (Thorpe, R.S., ed.), New York.

25. Samuel Gichile (1992). Granulites in the Precambrian basement of southern Ethiopia: P-T conditions of metamorphism and tectonic setting. Journal of African Earth Sciences 15:251-263.

26. Samuel Gichile and Fyson, W.K. (1993). An inference of the tectonic setting of the Adola Belt of southern Ethiopia from geochemistry of magmatic rocks. Journal of African Earth Sciences16:235-246. 
27. Seife Michael Berhe (1990). Ophiolites in Northeast and East Africa: implications for Proterozoic crustal growth. J. Geol. Soc. London 147:41-57.

28. Shackleton, R.M. (1986). Precambrian collision tectonics in Africa. In: Collision Tectonics. Geological Society. Special Publication, Vol. 19,pp. 329-352, (Coward, M.P. and Ries, A.C., eds). London.

29. Stern, R.J. (1994). Arc assembly and continental collision in the Neoproterozoic East African orogen. Ann. Rev. Earth Planet. Sci. 22:319-351.

30. Tadesse Kebede, Koeberl, C. and Koller, F. (1999). Geology, geochemistry and petrogenesis of intrusive rocks of the Wallagga area, western Ethiopia. J. African Earth Sci. 29:715-734.

31. Tadesse Kebede, Koeberl, C. and Koller, F. (2001). Magmatic evolution of the Suquii-Wagaa garnet-bearing two-mica granite, Wallagga area, western Ethiopia. J. African Earth Sci. 32:193-221.

32. Tadesse Kebede and Koeberl, C., (2002). Petrogensis of A-type granitoid from Wallagga area, western Ethiopia: Constraints from mineralogy, bulkrock chemistry, $\mathrm{Nd}$ and $\mathrm{Sr}$ isotopic compositions. Precambrian Research. (In press).

33. Teklewold Ayalew, Bell, K. and Moore, J.M. (1987). Magmatic arc intrusive complexes in the Birbir Domain, western Ethiopia. In: Current Research in African Earth Sciences, pp. 113-116. Balkema, Rotterdam.

34. Teklewold Ayalew and Moore, J.M. (1989). The Gore-Gambella Geotraverse, Western Ethiopia; Open File Report - IDRC; 153 pp.

35. Teklewold Ayalew (1997). Metamorphic and structural evolution of the GoreGambella area, Western Ethiopia. SINET: Ethiop. J. Sci. 20(2):235-259.

36. Teklewold Ayalew and Peccerillo, A. (1998). Petrology and geochemistry of the Gore-Gambella plutonic rocks: implications for magma genesis and the tectonic setting of the Pan-African Orogenic Belt of western Ethiopia. J. African Earth Sci. 27:397-416.

37. Teklewold Ayalew, Bell, K., Moore, J.M. and Parrish, R.R. (1990). U-Pb and Rb-Sr geochronology of the Western Ethiopian Shield. Geol. Soc. Am. Bull. 102:1309-1316.

38. Teklewold Ayalew, and Samuel Gichile (1990). Preliminary U-Pb ages from southern Ethiopia. In: Extended Abstracts of the $15^{\text {th }}$ Colloquium on African Geology, pp. 127-130. Nancy, France.

39. Vail, J.R. (1985). Relationship between tectonic terrains and favourable metallogenic domains in the Central Arabian-Nubian Shield. Institute of Mining and Metallurgy Transactions. Section B. Applied Earth Sciences 94:1-6.

40. Warden, A.J., Kazmin, V., Kiesel, W. and Pohl, W. (1982). Some geochemical data of mafi-ultramafic complex at Tulu-Dimtu, Ethiopia, and their genetic significance. Sitzungsberichten der Osterreichischen Akademie der Wissenschaften mathem-natur. 191:111-131.

41. Warden, A.J. and Horkel, A.D. (1984). The geological evolution of the northeast branch of the Mozambique Belt (Kenya, Somalia, Ethiopia). Mitteilungen Osterreich Geologische Gesellschaft 77:161-184. 